\title{
Heterogeneous distribution in sediments and dispersal in waters of Alexandrium minutum in a semi-enclosed coastal ecosystem
}

Klouch Z. K. 1,2, Caradec Florian ${ }^{1}$, Plus Martin ${ }^{1}$, Hernandez Farinas Tania 1,2, Pineau-Guillou Lucia ${ }^{3}$, Chapelle Annie 1, Schmitt Sophie ${ }^{1}$, Quere Julien ${ }^{1}$, Pineau-Guillou Lucia 2, 3, Siano Raffaele 1, *

1 IFREMER, DYNECO PELAGOS, Ctr Brest, F-29280 Plouzane, France.

2 Sorbonne Univ, UPMC Univ Paris 6, Stn Biol Roscoff,CNRS, Adaptat \& Diversite Milieu Marin UMR

7144,Equipe, PI Georges Teissier,CS90074, F-29688 Roscoff, France.

3 IFREMER, Ctr Brest, LOPS OC, F-29280 Plouzane, France.

* Corresponding author : Raffaele Siano, email address : raffaele.siano@ifremer.fr

\begin{abstract}
:
Within the framework of research aimed at using genetic methods to evaluate harmful species distribution and their impact on coastal ecosystems, a portion of the ITS1rDNA of Alexandrium minutum was amplified by real-time PCR from DNA extracts of superficial $(1-3 \mathrm{~cm})$ sediments of 30 subtidal and intertidal stations of the Bay of Brest (Brittany, France), during the winters of 2013 and 2015. Cell germinations and rDNA amplifications of $A$. minutum were obtained for sediments of all sampled stations, demonstrating that the whole bay is currently contaminated by this toxic species. Coherent estimations of ITS1rDNA copy numbers were obtained for the two sampling cruises, supporting the hypothesis of regular accumulation of $A$. minutum resting stages in the south-eastern, more confined embayments of the study area, where fine-muddy sediments are also more abundant. Higher ITS1rDNA copy numbers were detected in sediments of areas where blooms have been seasonally detected since 2012 . This result suggests that specific genetic material estimations in superficial sediments of the bay may be a proxy of the cyst banks of A. minutum. The simulation of particle trajectory analyses by a Lagrangian physical model showed that blooms occurring in the south-eastern part of the bay are disconnected from those of the north-eastern zone. The heterogeneous distribution of $A$. minutum inferred from both water and sediment suggests the existence of potential barriers for the dispersal of this species in the Bay of Brest and encourages finer analyses at the population level for this species within semi-enclosed coastal ecosystems.
\end{abstract}




\section{Graphical abstract}

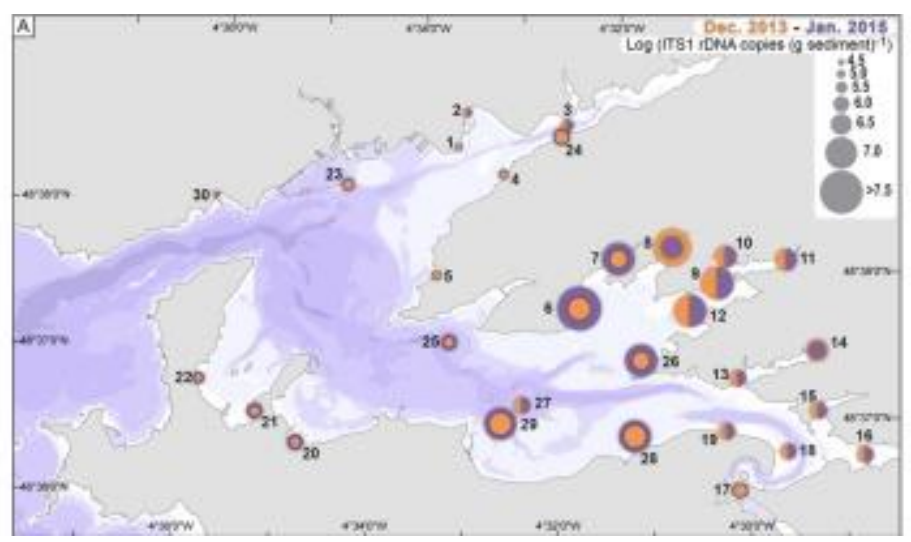

Keywords : Molecular ecology ; Dinoflagellate cyst ; Spatial distribution ; Real-time PCR ; Lagrangian model ; Population dynamics 


\section{Introduction}

The recovery of resting stages of harmful microalgae in sediment samples and the identification of accumulation sites indicate potential seeding sources for the initiation of blooms (Anderson et al., 2012). Cyst bank mapping is therefore particularly useful for the risk assessment of harmful microalgae, since it enables the prediction of blooming areas and the optimization of the management of coastal economic activities.

The distribution of Alexandrium species in coastal and shelf waters is relatively well known; however, comprehensive distributional data, especially for resting stage banks, are still needed (Anderson et al., 2012). On the basis of the available information, some common features in the distribution of Alexandrium cysts can be identified. Previous studies have reported that cyst accumulations are favored in fine-muddy rather than sandy sediments (White and Lewis, 1982, Kremp, 2000, Yamaguchi et al., 1996, Joyce et al., 2005, Gayoso et al., 2001, Matsuoka et al., 2003, Wang et al., 2004, Anderson et al., 2005, Anglès et al., 2010, Horner et al., 2011, Genovesi et al., 2013, Trikia et al., 2014, Fertouna-Bellakhal et al., 2015), supporting the hypothesis that dinoflagellate resting stages behave physically like fine particles (Dale, 1983). In semi-enclosed, confined ecosystems discrete cyst banks may be found (Anderson et al., 2012). A close link between the local distribution of cyst banks and blooms has been documented for some Alexandrium species in estuaries (Cembella et al., 1988, Crespo et al., 2011, Anderson et al., 2014), lagoons (Genovesi et al., 2009, Genovesi et al., 2013, Trikia et al., 2014, Fertouna-Bellakhal et al., 2015), and harbors (Bravo et al., 2008, Anglès et al. 2010). This local distribution has been associated with the hydrodynamic features of the studied ecosystems. Despite occurring in adjacent waters, local blooms of $A$. fundyense Balech were temporally separated, probably due to water retention in the first site where the blooms occurred (Crespo et al., 2011). Cyst densities of $A$. tamarense (Lebour) Balech were influenced by local hydrodynamics, with wind-induced currents causing cyst dispersal in the shallow ecosystem of the Thau lagoon (Genovesi et al., 2013). These examples prove the interest of 
characterizing discrete, fine spatial scale cyst distributions to deduce local bloom dynamics in semienclosed ecosystems.

Traditionally, hot spots of harmful microalgae accumulation in sediments are identified by microscopy counting of their cysts (Genovesi et al., 2013), a method that is time-consuming and suffers from taxonomical limitations in identification due to the lack of distinctive morphological characteristics for the cysts of some species. In contrast, the analysis of specific genetic material in sediment has proved to be a valuable alternative to infer cyst distribution, enabling a large number of samples to be processed objectively in a relatively short time. The amplification of species-specific marker genes from DNA preserved in sediment samples has been used to infer the presence of dinoflagellate cysts (Godhe et al., 2002, Penna et al., 2010). Real-time PCR amplification to quantify DNA genes from sediments has been shown to be agood proxy for cyst abundances, including some Alexandrium species (Kamikawa et al., 2007, Erdner et al., 2010, Park and Park, 2010). Lastly, cyst species have been mapped using the fluorescence in situ hybridization (FISH) technique (Hattenrath Lehmann et al., 2016). Genetic techniques can therefore be used to provide reliable information on accumulation spots of cysts and to infer ecological patterns. Given the close association between resting cyst abundance and sediment type, high specific DNA abundances should also b e found in the corresponding muddy sediments. The DNA extracted from sediments, however, can be of both intercellular (resting stages) (Godhe et al., 2002, Erdner et al., 2010) and extracellular origin (Pietramellara et al., 2009), making the relationship between specific DNA traces and sediment type not completely predictable and still barely studied.

Although the analysis of genetic material in sediment cores showed that A. minutum Halim has been present in the Bay of Brest since at least the 19th century (Klouch et al., 2016), the vegetative form of the species was first identified within the framework of the REPHY (REseau de surveillance et d'observation du PHYtoplankton et des PHYcotoxines: http://envlit.ifremer.fr/surveillance/phytoplancton_phycotoxines/presentation) in 1990. The first cyst abundance survey was carried out in the same year and no cyst of $A$. minutum was found in four 
estuarine stations of the Bay of Brest (Erard-Le Denn, 1993, Erard-Le Denn and Boulay, 1995). The species abundance increased over time in the bay, reaching the record concentration of ca. $42 \times 10^{6}$ cells ${ }^{-1}$ in July 2012 (Chapelle et al., 2015, Klouch et al., 2016) in the small, enclosed Daoulas estuary, where bloom occurrences were unsuspected and monitoring was not carried out. In parallel, other blooms of the species were observed in other estuaries on the bay (Elorn River, Aulne River), but these were of minorimportance $\left(<2 \times 10^{6}\right.$ cells $\left.^{-1}\right)$. After the 2012 event, monitoring of Daoulas Bay was initiated and seasonal blooms of $A$. minutum are observed in the Daoulas estuary along with blooms of lower cell abundance in other monitored estuaries. The development of different intensities in the Bay of Brest raises questions about the distribution of the major cyst banks of the species and the potential connectivity between its different adjacent estuarine ecosystems.

In this study, both genetic analyses of sediments and model simulations in the water column were used to try to explain the heterogeneity of $A$. minutum bloom occurrence in the Bay of Brest. With a recently developed real-time PCR assay (Klouch et al., 2016), the ITS1rDNA copy number of $A$. minutum from total DNA extracts of superficial sediments was quantified and used to infer the distribution of cyst banks in the area. In parallel, the viability of these banks in the sampled stations was determined in order to verify whether DNA genetic data correspond to viable resting stages of the organisms and not only to the amplification of extracellular DNA. By means of a Lagrangian physical model, passive particle trajectories released from different estuarine zones were simulated in order to study the potential dispersal of $A$. minutum cells of different blooms and the connectivity between different estuaries of the bay. The information gathered on both the benthic and the pelagic habitat contributes to the understanding of $A$. minutum bloom dynamics in the Bay of Brest and provides an example of heterogeneity in the dispersal of toxic microalgae in a semi-enclosed coastal area.

\section{Materials and Methods}

Study area 
The Bay of Brest (Brittany, France) is a semi-enclosed, marine ecosystem of $180 \mathrm{~km}^{2}$ connected to the Iroise Sea (Atlantic Ocean) by an opening $1.8 \mathrm{~km}$ wide and $\sim 50 \mathrm{~m}$ deep (Fig. 1). The bay is a shallow (about half of the total surface area is shallower than $5 \mathrm{~m}$ ) macrotidal coastal system. The semidiurnal tidal amplitude ranges from 1.2 to $7.3 \mathrm{~m}$ (average of $4 \mathrm{~m}$ ), leading to the presence of extended intertidal flats during low tides. Frequent storms can induce a resuspension of material and a very high turbidity (>100 $\mathrm{mgl}^{-1}$ of sediments) over a long period of time (Hily et al., 1992). The bay is characterized by fine and coarse sediments in shallow and deep waters, respectively, with a higher proportion of muddy sediments in the upstream part of the estuaries (Hily et al., 1989). The ecosystem hydrology is influenced by 5 different watersheds, with two main rivers, the Aulne (1842 $\mathrm{km}^{2}$ catchment area, $30 \mathrm{~m}^{3} \mathrm{~s}^{-1}$ interannual mean flow) flowing into the south basin and the Elorn (402 $\mathrm{km}^{2}$ catchment area, $5.63 \mathrm{~m}^{3} \mathrm{~s}^{-1}$ interannual mean flow) flowing into the north basin, contributing to about $80 \%$ of the total annual freshwater input. The total interannual mean flow has stabilized after a four-decade rise, while the anthropogenic loads of nitrogen and phosphorous have stabilized and decreased, respectively. The ban on washing powders containing orthophosphates in the last two decades has resulted in a decreased phosphorous supply and thus a significant imbalance in the N/P ratio (Chauvaud et al., 2000, Guillaud and Bouriel, 2007) which has led to changes in the composition of planktonic and benthic communities (Quéguiner and Tréguer, 1984, Del Amo et al., 1997, Chauvaud et al., 2000).

\section{Sampling strategy}

Thirty sites were selected in the Bay of Brest on the basis of available cartographies of sediment typologies and benthic biotopes. Sampled stations correspond to ecosystems where: i) cyst accumulation may be favored by the site geomorphology (estuaries, small bays with low flushing, low bioturbation rates), ii) genetic material could be better preserved (muddy, anoxic sediments), iii) human activities are developed and/or the impact of Harmful Algal Blooms is higher (harbors, shellfish farming areas). Twenty-three stations were located in intertidal zones and seven in subtidal 
areas (Table 1). Altogether, the 30 sampled stations cover well the geography of the Bay of Brest (Fig. 1). Samples were collected at low tide \pm 2 hours during two campaigns of 3-5 days, both carried out during the winter of two consecutive years (December 2013 and January 2015). Subtidal stations were sampled by scuba divers. The top $3 \mathrm{~cm}$ of sediments was collected in triplicate using plastic syringes at 1-2 m distance from each other. Sediment samples were carefully preserved in different tubes. Samples of DNA were immediately frozen in liquid nitrogen then stored at $-80^{\circ} \mathrm{C}$ in the laboratory while samples for cyst germination experiments were preserved in the dark at $4^{\circ} \mathrm{C}$. Samples were preserved at $4^{\circ} \mathrm{C}$ for granulometry, at $-80^{\circ} \mathrm{C}$ for chlorophyll $a$ and pheopigments, and at $-20^{\circ}$ for organic carbon (OC).

\section{Sediment analyses}

Granulometry, chlorophyll $a$, pheopigment and organic carbon $(\mathrm{OC})$ concentrations were determined from samples collected in triplicate at each station. Sediment grain size was analyzed using an LS 200 Beckman Coulter laser granulometer and sediment typologies were classified according to Larsonneur (1977) on the basis of four size classes (0-63, 63-125; 125-500; 500-2000 $\mu \mathrm{m}$ ). For chlorophyll and pheopigment concentration measurements, sediment samples were freeze-dried just before extraction and analysis (Reuss and Conley, 2005). Before extraction, the sample was homogenized, and gravel and shell debris were removed. Chlorophyll $a$ and pheopigments were extracted from $1 \mathrm{~g}$ of sediment with $10 \mathrm{ml}$ of $90 \%$ acetone for at least $12 \mathrm{~h}$ at $4^{\circ} \mathrm{C}$. Supernatants containing the extracted pigments were recovered after sample centrifugation. Chlorophyll $a$ and pheopigment concentrations were determined spectrophotometrically at 750 and $665 \mathrm{~nm}$ before and after sample acidification with $0.3 \mathrm{~N} \mathrm{HCl}$ (Lorenzen, 1967, Pusceddu et al., 2003). Sediment samples for $\mathrm{OC}$ measurement were ground and homogenized. Organic $\mathrm{C}$ was measured using a vario EL-III CNS elementary analyzer after decalcification of a subsample of the freeze-dried and ground sediment with phosphoric acid (Cauwet, 1975). Concentrations were calculated by comparison with 
samples of known concentration of organic carbon (acetanilide, sulfanilamide) and analyses were verified with a certified reference sediment sample.

\section{Molecular analyses}

Copy numbers of $A$. minutum ITS1rDNA were measured directly on DNA extracts from sediments using a newly developed real-time qPCR assay (Klouch et al., 2016). Total DNA was extracted from 10 $\mathrm{g}$ of sediment material from each triplicate of all stations using the PowerMax soil isolation kit (Mobio Laboratories Inc., Carlsbad, California, USA), following the manufacturer's instructions. Extracts of DNA were eluted in a final volume of $5 \mathrm{ml}$ and immediately stored at $-80^{\circ} \mathrm{C}$. Samples of DNA were quantified by absorbance measurements using a Take3 trio microplate reader (BioTek, Winooski, Vermont, USA) on $3 \mu$ l of DNA extract, and sterile water was used as the blank. The quality of DNA was checked by $260 / 280 \mathrm{~nm}$ ratio to ensure that no contamination by proteins or other components had occurred during DNA extraction.

Real-time PCR reactions were carried using primers Am_48F (5'-TGAGCTGTGGTGGGGTTCC-3') and Am_148R (5'-GGTCATCAACACAGCAGCA-3') which target a fragment of $100 \mathrm{bp}$, the optimal amplicon length for real-time PCR efficiency (Klouch et al., 2016). Prior to real-time PCR reactions, a standard curve was constructed by cloning the ITS1rDNA gene from a local culture of $A$. minutum (A89) into a plasmid ( $p C R$ 4) using a TOPOTA cloning kit (Invitrogen, USA). The standard curve was prepared with 10-fold serial dilutions of the plasmid containing the ITS1rDNA sequence of $A$. minutum and ranged from $10^{6}$ to 10 copies $\mu{ }^{-1}$. Real-time PCR (quantitative PCR or qPCR) reactions were performed using the iTaq Universal SYBR Green supermix kit (Bio-Rad) in a final volume of $20 \mu$ l. The reaction mixture was composed of $10 \mu \mathrm{l}$ of SYBR Green supermix (1X) containing (dNTPs, iTaq DNA polymerase, $\mathrm{MgCl}$, SYBR Green I), $0.3 \mu \mathrm{M}$ of the forward primer (Am_48F), $0.2 \mu \mathrm{M}$ of the reverse primer (Am_148R), sterile water and $2 \mu \mathrm{l}$ of DNA template. The experiments were conducted in 96-well plates containing the standard curve dilutions in duplicate, the target samples in triplicate and negative controls composed of water instead of DNA in duplicate. The plates were loaded onto a 

following cycling conditions: 1 cycle at $95^{\circ} \mathrm{C}$ for 5 min followed by 40 cycles of $95^{\circ} \mathrm{C}$ for 5 sec and $62^{\circ} \mathrm{C}$ for $30 \mathrm{sec}$. A melting curve analysis was added at the end of each run to ensure specific $A$. minutum amplification. The optimal annealing temperature of $62^{\circ} \mathrm{C}$ was initially determined in conventional PCR. The primer combination that yielded the lowest threshold cycle value $(\mathrm{Ct})$ and maximum realtime efficiency (Am_48F; $0.3 \mu \mathrm{M}$, Am_148R; $0.2 \mu \mathrm{M}$ ) was retained for further analysis. The reaction efficiency was estimated by the equation $E=10^{(1 / b)-1}$, where $b$ is the slope of the standard curve. To ensure specific amplifications, the melting temperature values $(\mathrm{Tm})$ were systematically checked by analyzing the melting curves. For further details, see Klouch et al. (2016). Abundances of $A$. minutum in each sample were expressed (assuming a 100\% DNA extraction efficiency) in terms of copy number perg of wet sediment, using the following formula: Copy number $\mathrm{xg}^{-1}=\operatorname{copy}$ number $\mu \mathrm{I}^{-1} \mathrm{x}$ DNA extraction volume $(\mu \mathrm{l}) /$ sediment wet weight $(\mathrm{g})$

\section{Cyst germination experiments}

Germination experiments were carried out on samples from the 2013 series. An aliquot of $\sim 5 \mathrm{~cm}^{3}$ of sediment samples was added to filtered seawater and placed in an ultrasonic bath for 6 min to separate dinoflagellate cysts from inorganic particles. The $20-100 \mu \mathrm{m}$ fraction of particles was retained for culturing experiments after sample sieving. Some drops of the $20-100 \mu m$ sediment fractions were distributed in 12-well plastic plates with K medium (Keller et al., 1987). The plates were placed in a culture room at $16^{\circ} \mathrm{C}$, under an irradiance of $60 \mu \mathrm{mol}$ photons $\mathrm{m}^{-2} \mathrm{~s}^{-1}$ and a light: dark cycle of $12 \mathrm{~h}: 12 \mathrm{~h}$. The plates were examined qualitatively once every day to check for $A$. minutum cell germination using an inverted microscope (Zeiss Axiovert 135). Germinated cells of $A$. minutum were identified using morphological characteristics (size, shape, plate arrangement). was used to study planktonic cell trajectories after bloom development. This numerical code solves 
primitive physics equations (e.g. Navier-Stokes under hydrostaticity and Boussinesq assumptions)

and is based on a finite difference scheme coupling barotropic and baroclinic modes within a sigmacoordinate framework. For this study, the model was defined for the Bay of Brest with spatial limits ranging between $48.203-48.447^{\circ} \mathrm{N}$ and $4.093-4.730^{\circ} \mathrm{W}$, a spatial horizontal resolution of 50 meters and 20 vertical layers. Moreover, the model assumed a wetting and drying capability (intertidal areas), which is mass preserving. The model's bathymetry was provided by the SHOM (French Naval Hydrographic and Oceanographic Service). At its western and southern boundaries, the model was forced for water elevation (tides), water temperature and salinity by another model (Lazure et al., 2009), previously validated for tides and hydrology and simulating the Bay of Biscay and Channel hydrodynamics. Atmospheric forcing (wind and atmospheric pressure) came from the Météo-France AROME model (Seity et al., 2011) which has a temporal resolution of 1 hour and a spatial resolution of $0.025^{\circ}$ (roughly $2.4 \mathrm{~km}$ ). The three major rivers, the Aulne, the Elorn and the Mignonne, were taken into account, and water flows came from the HYDRO database (Governmental Environment Agency). Trajectories of $A$. minutum cells were computed by the ICHTYOP Lagrangian transport tool (Lett et al., 2008) coupled with the hydrodynamic model of the bay. This tool enables offline simulations of bloom dispersion by calculating fictive particle trajectories based on previously calculated currents. Two simulations were run for years 2014 and 2015. Particles were released at the beginning of June, when Alexandrium bloom conditions were fulfilled according to Chapelle et al. (2015), i.e. when the water temperature was above $15^{\circ} \mathrm{C}$ and during a neap tide period. Four different starting points were tested: stations 3, 9, 13 and 16 (Fig. 1). At each station, 1,000 passive particles were released in the surface layer within a square stain of $100 \mathrm{~m}$ side length. Each particle position was recorded during 10 days of simulations, which is the approximate period before particles are flushed out of the bay. The level of dropping (surface or bottom) was tested but had no significant influence on the results (not shown here). For these simulations, it was also assumed that particles had no buoyancy, no mortality and no growth and that they could not wash up on the coast. 
the geographical limits of the four different estuarine areas: the Elorn estuary (incorporating station 3), the Daoulas estuary (incorporating station 9), the Camfrout estuary (incorporating station 13), and the Aulne estuary (incorporating station 16). Total numbers of particles released at each station and reaching the other three areas were computed. The model also enabled the calculation of the mean total distance covered by particles starting from the different stations as well as the total number of particles remaining in each area by the end of the simulation as a proxy for confinement.

\section{Statistical analyses}

A Principal Component Analysis (PCA) was used to assess relationships between environmental and biological data along a reduced number of axes (ade4 package for R; Dray and Dufour, 2007). Data used in the PCA included the four sediment size fractions (0-63 $\mu \mathrm{m}, 63-125 \mu \mathrm{m}, 125-500 \mu \mathrm{m}, 500-$ $2000 \mu \mathrm{m})$ and the three biological variables ( $\mathrm{Chl} a$, A. minutum and total DNA concentration). To reduce the importance of observations with very high values, concentrations of $A$. minutum ITS1rDNA copy number $\mathrm{g}^{-1}$ sediment were $\log 10(\mathrm{x}+1)$-transformed. The PCA result had the same dimension as the dataset, but the first principal components account as much as possible for the data variability. Thus, only the first two axes explaining most of the variance were retained for later interpretations. For graphical representation, PCA results were combined with a cluster analysis performed on environmental and biological variables (complete-linkage clustering, vegan package; Oksanen et al., 2015) to highlight further differences between station groups. A single cutting level (Euclidean distance $=8.2$ ) was selected to obtain major groups of samples. Prior to these analyses, all variables were centered and scaled in order to make them dimensionally homogenous. Finally, the Spearman rank correlation coefficients were calculated between all the environmental and biological variables. All statistical analyses were performed using the R software (R Core Team, 2015).

\section{Results}

Sediment analyses 
The relative magnitude of the granulometric size classes analyzed enabled each sampling site to be classified on the basis of their sediment typology (Supp. Table 1) for the two sampling surveys. Of the 30 sampling stations, 13 were classified as sandy-mud, 6 as mud, 1 as muddy-sand, and 2 as fine sand, coherently for both sampling surveys. For the remaining 8 stations, the granulometric classification varied between the two years, more often due to variations in the percentage of either or both 0-63 $\mu \mathrm{m}$ and $125-500 \mu \mathrm{m}$ sediment size fractions.

\section{Quantification of A. minutum in DNA extracts of sediments}

Total DNA concentrations extracted from the sediments ranged from 1.95 to $55.20 \mathrm{ng} \mathrm{hL}^{-1}$ for 2013

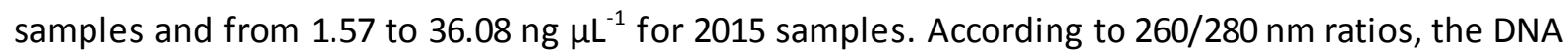
extracts were of sufficient yield and purity to conduct amplification analyses. The reaction efficiencies of real-time PCR amplifications of about $100 \mathrm{bp}$ of the ITS1rDNA of $A$. minutum ranged from 95 to $99 \%$ and the melting temperature values always corresponded to the expected value of $62^{\circ} \mathrm{C}$, both results proving the high resolution of the PCR assay performed in this study. The ITS1rDNA copy number varied from $1.63 \times 10^{4}$ to $5.46 \times 10^{7}$ copies $g^{-1}$ sediment in 2013 and from $2.89 \times 10^{4}$ to $5.47 \times 10^{7}$ copies $\mathrm{g}^{-1}$ sediment in 2015 . Local $A$. minutum quantification was very variable between replicates of some stations (the ranges of the standard errors between the three replicates were 3.57 $\times 10^{4}-2.63 \times 10^{7}$ and $8.06 \times 10^{4}-2.09 \times 10^{7}$ copies $g^{-1}$ sediment in 2013 and 2015 , respectively) showing a significant spatial variability for some stations at a very fine spatial scale (1-2 m) (Figs $2 A$, B). At some stations, one replicate differed from the other two in one sampling year and not in another (stations 1-10, 30), while for other stations the data between replicates were coherent for the two years of analyses (stations 11-19). Stations 16-29 were characterized by higher copy numbers in 2015 (Fig. 2B). Despite this strong intrasite variability, a coherent pattern of copy numbers of ITS1rDNA of $A$. minutum was identified between the two years. On the whole, both the intertidal (6-19) and subtidal (26-29) stations of the south-eastern part of the Bay of Brest were characterized by higher copy numbers than the subtidal and intertidal stations of the western (20-22, 
$25,30)$ and north-eastern part $(1-5,23-24)$ of the bay, in both 2013 and 2015. In particular, the intertidal stations within Daoulas Bay (6-12) and the subtidal station outside the bay (26-29) were characterized in both years by higher copy numbers of $A$. minutum ITS1rDNA (Fig. 2A).

\section{Germination experiments}

Germination of $A$. minutum occurred within the first 10 days of incubation of all (30/30) 2013 sediment samples. No differences (size, shape and swimming behavior) were observed in light microscopy between specimens of different localities. In the light of the 2013 successful germinations, cysts of the species were considered to have settled in all localities of the Bay of Brest and therefore germination experiments were not performed on 2015 sediment samples.

\section{Genetic and environmental data correlations}

The PCA performed with genetic, sediment granulometry and biological environmental parameters (Figs $3 \mathrm{~A}, \mathrm{~B}$ ) as well as Spearman correlations between variables (Fig. $3 \mathrm{C}$ ) showed that $A$. minutum ITS1rDNA copy numbers (labeled A. minutum DNA) and total DNA concentrations (labeled Total DNA) were positively correlated with the fine sediment size fraction (labeled 0-63 $\mu \mathrm{m}$ ), the Organic Carbon (labeled OC), and chlorophyll a (labeled CHLa) concentrations (Figs. 3A, C). In particular, A. minutum DNA was positively correlated with only fine sediment $(0-63 \mu \mathrm{m})(0.54)$ and not with coarser sediment types. The 0-63 $\mu \mathrm{m}$ sediment fraction and $A$. minutum DNA were both positively correlated with $\mathrm{OC}$ concentration ( 0.60 and 0.83 , respectively) (Fig. $3 \mathrm{C}$ ). Cluster analysis identified two major groups of stations (differentiated in dark (cluster 1) and light gray (cluster 2) in Fig. 3B). Overall, the analysis separates the south-eastern intertidal and subtidal sampling stations of the Bay of Brest (cluster 2: 6-12, 14-19, 26, 28, 29) where the highest percentages of the fine sediment size fraction (0-63 $\mu \mathrm{m})$ were associated with the highest concentrations of $\mathrm{OC}, \mathrm{CHL} a$ and genetic material, from the western and north-eastern stations (cluster 1: 1, 3-5, 20-22, 25, 30) where measured values of these variables were lower. Yet, some exceptions to this geographical separation of sampling stations 
were highlighted. Eastern stations 13 and 27 were characterized by low correlations and were grouped within cluster 1 . On the contrary, the north-eastern station 24 was grouped within cluster 2 , showing that the strong association between fine sediment granulometry, $\mathrm{OC}$ and $\mathrm{CHL} a$ and $A$. minutum copy number was not exclusive to a part of the Bay of Brest. Stations 2 and 23 had the same number of replicates in both clusters 1 and 2.

\section{Simulation of particle trajectories in the water}

Simulated trajectories and final particle positions after 10 days as a function of the initial release location and the year are shown in Figure 4 A-D as an example for 2015 (2014 simulated trajectories are not shown). Whichever year is considered, 56 to $81 \%$ of passive particles remain in the Bay of Brest after 10 days (Table 2). Particles released at Station 9 (Daoulas estuary) show the lowest percentage being flushed out of the Bay of Brest (Fig. 4B, Table 2), whilst particles released at station 3 (Elorn estuary) show the highest percentage (Fig. 4A, Table 2). The model simulations also show that particles released at stations 13 (Fig. 4C) and 16 (Fig. 4D) tend to be transported over greater distances than those released at stations 3 or 9 . The Daoulas estuary appears to be the most confined area with $26.5-26.2 \%$ (depending on years) of the initial number of particles released at station 9 remaining in that area after 10 days (Table 2). The connectivity table between the four release areas (Table 3) shows similar patterns for 2014 and 2015 simulations. As expected, stations 13 and 16 show a high connectivity with the nearby Daoulas estuary ( from 29.7 to $30.7 \%$ of the initial released particles). Interestingly, this connectivity seems to be rather one-way (from stations 13 or 16 towards the Daoulas estuary) since very few particles starting from station 9 (Daoulas estuary) reach the Camfrout estuary (0-0.4\%) or the Aulne estuary (7.8-8.5\%). The Daoulas and Elorn estuaries seem particularly hydrodynamically disconnected with very few particles released at station 9 reaching the Elorn estuary $(0.2-0.3 \%)$ and similarly from station 3 to the Daoulas estuary $(1.2-1.4 \%$ of particles). Moreover, after 10 days of simulation, no particle released from station 3 reaches the 
releasing station. Overall, the simulations described here demonstrate that the south-east of the bay is quite disconnected from the Elorn estuary, which is the area exporting the highest proportion of particles outside the Bay of Brest, and that the Daoulas estuary is a confined area with little connectivity with the Aulne estuary and even less with the Elorn estuary.

\section{Discussion}

Genetic mapping of A. minutum in sediments

In this study, a geographically exhaustive survey of the presence of A.minutum in superficial sediment of the Bay of Brest (Brittany, France) during the winter of two consecutive years (December 2013 and January 2015) is provided. This is not the first screening of $A$. minutum traces in sediment of the study area. In 1990, no cyst of $A$. minutum was found in four estuarine stations of the Bay of Brest (Erard-Le Denn et al., 1993, Erard-Le Denn and Boulay, 1995) using cyst identification by light microscopy. Here, real-time PCR amplification of a fragment of the ITS1rDNA of $A$. minutum from DNA sediment extracts was proposed as an alternative method to cyst quantification. The high proportion of extracellular DNA in the total environmental DNA extracts from sediments (Dell'Anno and Danovaro, 2005) is an important issue to take into account when performing specific DNA quantification in sediments. This problem may lead to misinterpreting the presence of viable material (resting stages) in sediment and bias estimations of cyst abundances. Methods to separate extracellularfrom intracellular DNA have been developed (Corinaldesi et al., 2005, Alawi et al., 2014, Lever et al., 2015) but, even when this separation has not been directly applied, specific DNA amplifications by PCR methodologies in field sediment samples have been shown to be a good proxy of cyst abundances (Gohde et al., 2002, Erdner et al., 2010, Penna et al., 2010, Klouch et al., 2016), most probably due to the better preservation of DNA material in resting stages (Boere et al., 2011). The number of copies of genomic DNA markers and its variability among strains and growth phase stages in dinoflagellates, including Alexandrium spp. (Galluzzi et al., 2010) and A. minutum in particular (Galluzzi et al., 2004), may also cause a misinterpretation of the exact dinoflagellate cell 
numbers in field samples when applying real-time PCR analyses. This issue has been discussed in several studies focusing on the efficiency and limitations of the real-time PCR methodology (Gohde et al., 2002, Gohde et al., 2008, Erdner et al., 2010, Galluzzi et al., 2010, Penna et al., 2010) underlining the importance of taking into account this variability when monitoring HAB species. The objective of this work was not to validate the real-time PCR amplifications to estimate exactly the cyst abundances of $A$. minutum, but to map potential accumulation zones in the study area in order to contribute to the understanding of the spatial heterogeneity of bloom dynamics and intensities of A. minutum in the estuaries of the Bay of Brest.

Genetic traces of $A$. minutum were found in 30 out of 30 sampled stations of the study area. In parallel, successful germination experiments of A. minutum on 2013 sediment samples proved that living resting stages had settled in all stations and that the toxic species currently contaminates the whole Bay of Brest. The reduced interstitial space between fine particles decreases water circulation and can favor the establishment of anoxia in sediments, which are suitable conditions for slowing the digenetic process and preserving organic matter (Genovesi et al., 2013). Therefore, as expected, the organic matter content, chl $a$ and total DNA concentrations were higher in stations characterized by fine sand-muddy sediment typology, as proved for instance by the high correlation value $(0.83)$ obtained between the finest sediment fraction $(0-63 \mu \mathrm{m})$ and the organic carbon content (Fig. 3). It is acknowledged that Alexandrium cysts behave physically like fine particles and that accumulation spots mostly occur in fine sediment areas (White and Lewis, 1982, Kremps, 2000, Yamaguchi et al., 1996, Joyce et al., 2005, Gayoso et al., 2001, Matsuoka et al., 2003, Wang et al., 2004, Anderson et al., 2005, Anglès et al., 2010, Horner et al., 2011, Genovesi et al., 2013). Consequently, DNA traces of the species should mostly be found in sediments characterized by a large fraction of fine particles. The good positive correlation found between the A. minutum ITS1rDNA amplifications and the 0-63 $\mu \mathrm{m}$ sediment fraction of the sampled stations confirms this hypothesis. Good correlations between ITS1rDNA amplifications and the 0-63 $\mu \mathrm{m}$ sediment fraction were coherent for both 2013 and 2015 samples in stations of the south-eastern part of the Bay of Brest and particularly for stations of the 
Daoulas estuary, in areas that were confirmed to be of muddy-fine sediment facies in a recent comprehensive, morpho-sedimentological analysis of the Bay of Brest (Gregoire et al., 2016).

Seasonal blooms of A. minutum have been detected in the Daoulas estuary since July 2012, when a massive toxic bloom event (concentrations of $42 \times 10^{6}$ cells $^{-1}$ ) highlighted the Daoulas area as a new risky zone for toxic blooms of A. minutum in the Bay of Brest (Chapelle et al., 2015). Before this event, the Daoulas area was not included in the monitored area of the REPHY observation network; in fact, the toxic species has only recently increased in the area as demonstrated by paleogenetic data from ancient sediment cores of the area (Klouch et al., 2016). As well as Daoulas Bay, blooms of the species occur in other zones of the Bay of Brest, but they have always been of minor intensity (Chapelle et al., 2015). In conclusion, large numbers of copies of the marker gene of A. minutum were found in sediments or areas where blooms of higher intensity occur in the plankton. This leads to the suggestion that the Daoulas estuary is probably an accumulation zone of cysts of $A$. minutum in the Bay of Brest, an area which should be carefully monitored for toxic bloom occurrences.

\section{Spatial heterogeneity in sediment and in water}

The mapping of the potential accumulation spots of $A$. minutum obtained for December 2013 and January 2015 suggests a non-homogenous distribution of cyst banks within the Bay of Brest, with major accumulation areas in the south-eastern part of the bay. In parallel, the simulation of passive particle trajectories performed with real forcings in potential offspring periods of $A$. minutum (June 2014 and 2015, the summer periods after the wintertime cyst accumulation in 2013 and 2015) suggests a differential dispersal of blooms in the bay. Blooms occurring in the south-eastern Daoulas estuary would be relatively disconnected from those in the north-eastern Elorn estuary, as the connectivity between the two areas is very low $(<1.4 \%)$. The reasons for this heterogeneity in cyst banks and potential bloom dispersal must be found in the hydrology, geomorphology, and hydrodynamics of the bay. 

ecosystems for dinoflagellate bloom occurrence because of a sustained nitrogen supply from rivers (Menesguen et al., 2006) and significant estuarine nutrient stocks in sediment (Raimonet et al., 2013) that can be resuspended (Tallberg et al., 2006) and due to low flushing rates in estuaries that allow the development of the bloom (Sourisseau et al., accepted). Despite high nutrient loads, the Bay of Brest seems to be resistant to eutrophication problems due to strong semi-diurnal tidal currents that ensure the water exchange with the continental shelf (Le Pape and Menesguen, 1997, Chavaud et al., 2000). In the shallow estuarine ecosystems of the Bay of Brest, the tide and the wind intensity and direction could promote bottom currents that can influence cyst and sediment distributions as shown in other semi-enclosed ecosystems (e.g. Genovesi et al., 2013, Trikia et al., 2014). Weak bottom currents favor the settlement of fine-muddy $(<0.63 \mu \mathrm{m})$ sediment and cysts of Alexandrium, which are acknowledged to behave like fine sediment particles (Dale, 1983). Therefore, bottom currents in the Bay of Brest may play a role in promoting the sediment movement and creating permanent superficial deposits of $A$. minutum in the shallow, peripheral embayments of the southeastern zone of the bay, such as the Daoulas estuary. The specificity of the distribution pattern of $A$. minutum in sediments of the Bay of Brest remains to be demonstrated. The cysts of different species showed different abundance patterns in the same ecosystem (Park and Park, 2010, Satta et al., 2013, Fertouna-Bellakhal et al., 2014). Therefore, the cysts of other dinoflagellate species might be characterized by a different distribution in the Bay of Brest. by hydro-sedimentary model simulations. Tide currents would generate higher concentrations of resuspended muddy sediments in the south-eastern estuaries of the bay (the Daoulas and Aulne estuaries) than in the north-eastern estuary (Elorn estuary) (Beudin et al., 2013, Beudin et al., 2014). Tracked suspended mud of the south-eastern estuaries is predicted to be flushed out of the bay, without reaching the Elorn estuary, while the mud of the Elorn estuary is expected to remain and redeposit in the estuarine area without reaching the inner and south-eastern parts of the Bay of 
Brest (Beudin et al., 2013, Beudin et al., 2014). In parallel, the simulated particle dispersal trajectories

468

469

470

471

472

473

474

475

476

477

478

479

480

481

482

483

484

485

486

487

488

489

490

491

492

suggest tidal currents coupled with river outflows would trigger current trajectories that cause low exchanges between the north-eastern Elorn estuary and the south-eastern Daoulas, Camfrout and Aulne estuaries. Potential blooms developing in the Elorn estuary would be mostly directly exported out of the bay, whereas blooms developing in each of the south-eastern estuaries would be connected to each other but not to the Elorn estuary. Simulations of both sediment and particle transport suggest that the hydrodynamics of the bay would create barriers for $A$. minutum dispersal. Consequently, there could be low interbreeding between populations of the northern and southern zones of the Bay of Brest. The simulations carried out in this study are based on a physical model that does not include biological variables such as growth, asexual and sexual reproduction and mortality rates. These variables affect the retention time of a bloom and the connectivity between ecosystems and populations of the bay. New model simulations that integrate biological variables and a population genetic approach would complete the information provided by this study, probably supporting the heterogeneity of $A$. minutum dispersal in the Bay of Brest.

\section{Conclusions}

The successful germination of $A$. minutum from all sampled stations of the Bay of Brest demonstrates that $A$. minutum currently contaminates the whole Bay of Brest. Since in 1990 no cysts were found in estuarine samples of the bay, the information provided in this study contribute s to highlighting a relatively recent proliferation of this toxic species in the bay. Higher copy numbers of ITS1rDNA in sediment samples of the Daoulas estuary argue in favor of the possibility that this estuary could be a major accumulation spot of the cysts of $A$. minutum. This distribution pattern could explain the regular occurrence of blooms of higher intensity in this area of the bay. The simulations of particle trajectories demonstrate that the blooms occurring in the north- and south-eastern estuaries of the bay are disconnected and therefore rather independent of each other. This suggests the existence of potential physical barriers to $A$. minutum bloom dispersal and of populations interbreeding in the 
bay. Overall, a heterogeneous distribution of $A$. minutum in both sediment and the water column emerge from this study, proving that there may be discrete, localized accumulations of cysts even in a semi-enclosed coastal ecosystem.

\section{Acknowledgements}

This work was financed by the DAOULEX project supported by the Region Bretagne. This research was carried out within the framework of K. Klouch's PhD funded by Ifremer and Region Bretagne (Allocation de REcherche Doctorale (ARED) fellowship) and by the project of the ECosphere Continentale et CÔtière (EC2CO) initiative of the Institut National des Sciences de I'Univers/Centre National de la Recherche Scientifique (INSU/CNRS): PALMITO (2013-2015). The authors wish to thank all colleagues who helped with sample collection and Xavier Caisey for scuba diving sampling assistance. We wish to thank Dominique Hervio-Heath and members of the SG2M/LSEM laboratory of Ifremer for access to their laboratory facilities and all their technical suggestions. Pierre Bodenes is acknowledged for collaborating in the picture developments and Pascale Malestroit for helping with culture maintenance. This research falls within the scope of the French GDR (Groupement de Recherche) Phycotox (http://www.phycotox.fr) (2012-2018) on harmful microalgae and phycotoxins.

\section{References}

Alawi M., Schneider, B., Kallmeyer, J., 2014. A procedure for separate recovery of extra- and intracellular DNA from a single marine sediment sample. J Microbiol Methods, 104, 36-42.

Anderson, D.M., Stock, C.A., Keafer, B.A., Nelson, A.B., Thompson, B., McGillicuddy, D.J. Jr., Keller, M., Matrai, P.A., Martin, J., 2005. Alexandrium fundyense cyst dynamics in the Gulf of Maine. DeepSea Res Pt II 52, 2522-2542. 
Anderson, D.M., Alpermann, T.J., Cembella, A.D., Collos, Y., Masseret, E., Montresor, M., 2012. The globally distributed genus Alexandrium: Multifaceted roles in marine ecosystems and impacts on human health. Harmful Algae 14, 10-35.

Anderson, D.M., Keafer, B.A., Kleindinst, J.L, McGillicuddy, D.J. Jr., Martin, J.L., Norton, K., Pilskaln, C.H., Smith, J.L., Sherwood, C.R., Butman, B., 2014. Alexandrium fundyense cysts in the Gulf of Maine: long-term time series of abundance and distribution, and linkages to past and future blooms. DeepSea Res Pt II 103, 6-26.

Anglès, S., Jordi, A., Garcés, E., Basterretxea, G., Palanques, A., 2005. Alexandrium minutum resting cyst distribution dynamics in a confined site. Deep-Sea Res Pt II 57, 210-221.

Beudin, A., Chapalin, G., Guillou, N., 2013. Suspended sediment modeling in the Bay of Brest impacted by the slipper limpet Crepidula fornicata. Proceedings of the $7^{\text {th }}$ International Conference on Coastal Dynamics, pp. 193-202.

Beudin, A., Chapalin, G., Guillou, N., 2014. Modelling dynamics and exchanges of fine sediments in the Bay of Brest. La Houille Blanche 6, 47-53

Boere, A.C., Sinninghe Damsté, J.S., Rijpstra, W.I.C., Volkman, J.K., Coolen, M.J.L., 2011. Sourcespecific variability in post-depositional DNA preservation with potential implications for DNA based paleoecological records. Org Geochem 42, 1216-1225.

Bravo, I., Vila, M., Maso, M., Figueroa, R.I., Ramilo, I., 2008. Alexandrium catenella and Alexandrium minutum blooms in the Mediterranean Sea: toward the identification of ecological niches. Harmful Algae 7, 515-522. 
545 Cauwet, G., 1975. Optimization of an analytical technique for evaluation of organic carbon in 546 sediments. Chem Geol 16, 59-63.

547

548 Cembella, A.D., Turgeon, J., Therriault, J.C., Beland, P., 1988 Spatial distribution of Protogonyaulax 549 tamarensis resting cysts in nearshore sediments along the north coast of the lower St. Lawrence 550 estuary. J Shellfish Res 7, 597-610.

551

552

Chapelle, A., Le Gac, M., Labry, C., Siano, R., Quéré, J., Caradec, F., Le Bec, C., Nézan, E., Doner, A. Jeremie G., 2015. The Bay of Brest (France), a new risky site for toxic Alexandrium minutum blooms and PSP shellfish contamination. Harmful Algae News, 51, 4-5.

555

Chauvaud, L., Jean, F., Ragueneau, O., Thouzeau, G., 2000. Long-term variation of the Bay of Brest ecosystem: benthic-pelagic coupling revisited. Mar Ecol-Prog Ser 200, 35-48.

Corinaldesi, C., Barucca, M., Luna, G., Dell'Anno, A., 2011. Preservation, origin and genetic imprint of extracellular DNA in permanently anoxic deep-see sediments. Mol Ecol 20, 642-654.

561

Crespo, B.G., Keafer, B.A., Ralston, D.K., Lind, H., Farber, D., Anderson, D.M., 2011. Dynamics of Alexandrium fundyense blooms and shellfish toxicity in the Nauset Marsh System of Cape Cod (Massachusetts, USA). Harmful Algae 12, 26-38.

565 

362.

Del Amo, Y., Quéguiner, B., Tréguer, P., Breton, H., Lampert, L., 1997. Impacts of high-nitrate freshwater inputs on macrotidal ecosystems. II. Specific role of the silicic acid pump in the year-round dominance of diatoms in the Bay of Brest (France). Mar Ecol Prog Ser 161, 225-237.

Dray, S., Dufour, A.B., 2007. The ade4 package: implementing the duality diagram for ecologists. J Stat Softw 22, 1-20.

Dell'Anno, A., Danovaro, R., 2005. Extracellular DNA plays a key role in deep-sea ecosystem functioning. Science 309, 2179.

Erard-Le Denn, E., Desbruyeres, E., Olu, K., 1993. Alexandrium minutum: resting cyst distribution in the sediments collected along the Brittany coast, France. In: Smayda, T.J., Shimizu, Y. (Eds), Toxic Phytoplankton in the Sea, Elsevier Science Publisher, Amsterdam, pp. 109-114

Erard-Le Denn, E., Boulay, V., 1995. Resting cysts of Alexandrium minutum in marine sediments: quantification by three methods. In: Lassus, P., Arzul, G., Erard-Le Denn, E., Gentien, P., Marcaillou-Le Baut, C. (Eds), Harmful Marine Algal Blooms, Lavoisier Publishing, Paris, pp. 257-730

Erdner, D.L., Percy, L., Keafer, B., Lewis, J., Anderson, D.M., 2010. A quantitative real-time PCR assay for the identification and enumeration of Alexandrium cysts in marine sediments. Deep-Sea Res Pt II 57, 279-87. 
607

Fertouna-Bellakhala, M., Dhib, A., Fathalli, A., Bellakhal, M., Chomérat, N., Masseret, E., Laabir, M., Turkic, S., Aleyaa, L., 2015. Alexandrium pacificum Litaker sp. nov (Group IV): Resting cyst distribution and toxin profile of vegetative cells in Bizerte Lagoon (Tunisia, Southern Mediterranean Sea). Harmful Algae 48, 69-82.

Galluzzi, L., Penna, A., Bertozzini, E., Vila, M., Garcés, E., Magnani, M., 2004. Development of a realtime PCR assay for rapid detection and quantification of Alexandrium minutum (a dinoflagellate). Appl Environ Microbiol 70, 1199-1206.

Galluzzi, L., Bertozzini, E., Penna, A., 2010. Analysis of rRNA gene content in the Mediterranean dinoflagellate Alexandrium catenella and Alexandrium taylorii: implications for the quantitative realtime PCR-based monitoring methods. J Appl Phycol 22, 1-9.

Gayoso, A.M., 2001. Observation on Alexandrium tamarense (Lebour) Balech and other dinoflagellate population in Golfo Nuevo, Patagonia (Argentina). J Plankton Res 23, 463-468.

Genovesi, B., Laabir, M., Masseret, E., Collos, Y., Vaquer, A., Grzebyk, D., 2009. Dormancy and germination features in resting cysts of Alexandrium tamarense species complex (Dinophyceae) can facilitate bloom formation in a shallow lagoon (Thau, southern France). J Plankton Res 31, 12091224.

Genovesi, G., Mouillot, D., Laugier, T., Fiandrino, A., Laabir, M., Vaquer A., Grzebyk D., 2013. Influences of sedimentation and hydrodynamics on the spatial distribution of Alexandrium catenella/tamarense resting cysts in a shellfish farming lagoon impacted by toxic blooms. Harmful Algae 25, 15-25. 
Gregoire, G., Ehrhold, A., Le Roy, P., Jouet, G., Garlan, T., 2016. Modern morpho-sedimentological patterns in a tide-dominated estuary system: the Bay of Brest (west Brittany, France). J Maps. http://doi.org/10.1080/17445647.2016.1139514

Godhe, A., Rehnstam-Holm, A.S., Karunasagar, I., Karunasagara, I., 2002. PCR detection of dinoflagellate cysts in field sediment samples from tropic and temperate environments. Harmful Algae 1, 361-73.

Gohde, A., Asplund, M.E., Hamstrom, K., Saravanan, V., Tyagi, A., Karunasagar, I., 2008. Quantification of diatom and dinoflagellate biomasses in coastal marine seawater by real -time PCR. Appl Environ Microbiol 74, 7174-7128.

Guillaud, J.-F., Bouriel, L., 2007. Relation concentration-débit et évolution temporelle du nitrate dans 25 rivières de la région Bretagne (France). RSE 20, 213.

Hattenrath-Lehmann, T.K., Zhen, Y., Wallace, R.B., Tang, Y.Z., Gobler, C.J., 2016. Mapping the distribution of cysts from the toxic dinoflagellate Cochlodinium polykrikoides in bloom-prone estuaries by a novel fluorescence in situ hybridization assay. Appl Environ Microb 82, 1114-1125.

Hily, C., 1989. La megafaune benthique des fonds meubles de la rade de Brest: pré-échantillonage par vidéo sous-marine. Cah Biol Mar 30, 433-454.

Horner, R.A., Greengrove, C.L., Davies-Vollum, K.S., Gawel, J.E., Postel, J.R., Cox, A.M., 2011. Spatial distribution of benthic cysts of Alexandrium catenella in surface sediments of Puget Sound, Washington, USA. Harmful Algae 11, 96-105. 
644

651

652

653

654

655

656

657

658

659

660

661

662

663

664

665

666

667

668

Joyce, L.B., Pitcher, G.C., du Randt A., Monteiro, P.M.S., 2005. Dinoflagellate cysts from surface sediments of Saldanha Bay, South Africa: an indication of the potential risk of harmful algal blooms. Harmful Algae 4, 309-318

Kamikawa, R., Nagai, S., Hosoi-Tanabe, S., Itakurab, S., Yamaguchi, M., Uchida, Y., Baba, T., Sakoa, Y., 2007. Application of real-time PCR assay for detection and quantification of Alexandrium tamarense and Alexandrium catenella cysts from marine sediments. Harmful Algae 6, 413-20.

Keller, M.D., Selvin, R.C, Claus, W., Guillard R.R.L., 1987. Media for the culture of oceanic ultraphytoplankton. J Phycol 23, 633-38.

Klouch, Z.K., Schmidt, S., Andrieux-Loyer, F., Le Gac, M., Hervio-Heath, D., Qui-Minet, Z. N., Quéré, J., Bigeard, E., Guillou, L., Siano, R., 2016. Historical records from dated sediment cores reveal the multidecadal dynamic of the toxic dinoflagellate Alexandrium minutum in the Bay of Brest (France). FEMS Microbiol Ecol 92, http://doi.org/10.1093/femsec/fiw101

Kremp, A., 2000. Distribution, dynamics and in situ seeding potential of Scrippsiella hangoei (Dinophyceae) cyst populations from the Baltic Sea. J Plankton Res 22, 2155-2169.

Larsonneur, C., 1977. La cartographie des dépôts meubles sur le plateau continental français: methode mise au point et utilisée en Manche. J Rech Océanogr 2, 3439.

Lazure, P., Dumas, F., 2008. An external-internal mode coupling for a 3D hydrodynamical model for applications at regional scale (MARS). Adv Water Resour 31, 233-250. 
675

676

677

678

679

680

681

682

683

684

685

686

687

688

689

690

691

692

Lazure P., GarnierV., Dumas F., Herry, C., Chifflet, M., 2009. Development of a hydrodynamic model of the Bay of Biscay. Validation of hydrology. Cont Shelf Res 29, 985-997.

Le Pape, O., Menesguen, A., 1997. Hydrodynamic prevention of eutrophication in the Bay of Brest (France), a modelling approach, in: Ruddick, K. (Ed.) Processes in regions of freshwater influence (PROFILE). J Marine Syst 12, 171-186

Lett, C., Verley, P., Mullon, C., Parada, C., Brochier, T., Penven, P., Blanke, B., 2008. A Lagrangian tool for modelling ichthyoplankton dynamics. Environ Modell Softw 23, 1210-1214.

Lever, M.A., Torti, A., Eickenbusch, P., Michaud, A.B., Šantl-Temkiv, T., Jørgensen, B.B., 2015. A modular method for the extraction of DNA and RNA, and the separation of DNA pools from diverse environmental sample types. Front Microbiol 6, 476.

Lorenzen, C.J., 1967. Determination of chlorophyll and pheopigments: spectrophotometric equations. Limnol Oceanogr 12, 343-346.

Matsuoka, K., Joyce, L.B., Kotani, Y., Matsuyama, Y., 2003. Modern dinoflagellate cysts in hypertrophic coastal waters of Tokyo Bay, Japan. J Plankton Res 25, 1461-1470.

Menesguen, A., Cugier, P., Leblond, I., 2006. A new numerical technique for tracking chemical species in a multisource, coastal ecosystem applied to nitrogen causing Ulva blooms in the Bay of Brest (France). Limnol Oceanogr 51, 591-601.

Oksanen, J., Blanchet, G.F., Kindt, R., Legendre, P., Minchin, P.R., O'Hara, R.B., Simpson, G.L., Solymos, P., Stevens, M.H.H, Wagner, H., 2015. Vegan: Community Ecology Package. R package version 2.3-0. http://CRAN.R-project.org/package=vegan. 
Park, T.G., Park, Y.T., 2010. Detection of Cochlodinium polykrikoides and Gymnodinium impudicum

(Dinophyceae) in sediment samples from Korea using real-time PCR. Harmful Algae 9, 59-65.

698

Penna, A., Battocchi, C., Garcés, E., Anglès, S., Cucchiari, E., Totti, C., Kremp, A., Satta, C., Giacobbe,

M.G., Bravo, I., Bastianini, M., 2010. Detection of microalgal resting cysts in European coastal sediments using a PCR-based assay. Deep-Sea Res Pt II 57, 288-300.

702

703

Pietramellara, G., Ascher, J., Borgogni, F., Ceccherini, M.T., Guerri, G., Nannipieri, P., 2009.

704

Extracellular DNA in soil and sediment: fate and ecological relevance. Biol Fert Soils 45, 219-35.

705

706

Pusceddu, A., Dell'Anno, A., Danovaro, R., Manini, E., Sara, G., Fabiano, M., 2003. Enzymatically 707

hydrolyzable protein and carbohydrate sedimentary pools as indicators of the trophic state of detritus sink systems: A case study in a Mediterranean coastal lagoon. Estuaries 26, 641-650.

709

710

Quéguiner, B., Tréguer, P. (1984). Studies on the Phytoplankton in the Bay of Brest (Western Europe).

711

712

713

714

715

716 temperate estuary: focus on P and Si cycles. Biogeochemistry 115, 399-417. features (1981-1982). Bot Mar 27, 449-460. Austria. http://www.r-project.org/.

Seasonal variations in composition, biomass and production in relation to hydrological and chemical

R Development Core Team. 2015. R: a Language and Environment for Statistical Computing. Vienna,

Raimonet, M., Andrieux-Loyer, F., Ragueneau, O., Michaud, E., Kerouel, R., Philippon, X., Nonent, M., Memery, L., 2013. Strong gradient of benthic biogeochemical processes along a macrotidal 
Reuss, N., Conley, D.J., 2005. Effects of sediment storage conditions on pigment analyses. Limnol Oceanogr-Meth 3, 477-487.

Satta, C.T., Anglès, S., Lugliè, A., Guillén, J., Sechi, N., Camp, J., Garcés, E., 2013. Studies on dinoflagellate cyst assemblages in two estuarine Mediterranean bays: a useful tool for the discovery and mapping of harmful algal species. Harmful Algae 24, 65-79.

Seity, Y., Brousseau, P., Malardel, S., Hello, G., Bénard, P., Bouttier, F., Lac, C., Masson, V., 2011. The AROME-France convective scale operational model. Mon Weather Rev 139, 976-991.

Sourisseau, M., Le Guennec, V., Le Gland, G., Plus, M., Chapelle, A., 2016. Understanding phytoplankton's ecological niche and phenology using traits-based models applied to toxic algae. Frontiers (accepted).

Tallberg, P., Tréguer, P., Beucher, C., Corvaisier, R., 2008. Potentially mobile pools of phosphorus and silicon in sediment from the Bay of Brest: Interactions and implications for phosphorus dynamics. Estuar Coast Shelf S 76, 85-94.

Trikia, H.Z., Daly-Yahiaa, O.K., Maloucheb, D., Komihaa, Y., Deidunc, A., Brahimd, M., Laabir, M., 2014. Distribution of resting cysts of the potentially toxic dinoflagellate Alexandrium pseudogonyaulax in recently-deposited sediment within Bizerte Lagoon (Mediterranean coast, Tunisia). Mar Pollut Bulletin 84, 172-181.

Wang, Z., Qi, Y., Lu, S., Wang, Y., Matsuoka, K., 2004. Seasonal distribution of dinoflagellate resting cyst in surface sediment from Changjang River Estuary. Phycol Res 52, 387-395. 
747 White, A.W., Lewis, C.M., 1982. Resting cysts of the toxicred tide dinoflagellate Gonyaulax excavata 748 in Bay of Fundy sediments. Can J of Fish Aquat Sci 39, 1185-1194.

749

750 Yamaguchi, M., Itakura, S., Nagasaki, K., Imai, I., Yasumoto, T., Oshima, Y., Fukuyo, Y. (Eds), 1996.

751

Distribution and Abundance of Resting Cysts of the Toxic Dinoflagellates Alexandrium tamarense and

752

A. catenella in sediments of the eastern Seto Inland Sea, Japan, Intergovernmental Oceanographic

753 Commission of UNESCO, Laboratory of Bioorganic Chemistry, Tohoku University, Japan pp. 177-180.

754

755

756

757

758

759

760

761

762

763

764

765

766

767

768

769

770

771 
773

774

775

776

777

778

779

780

781

782

783

784

785

786

787

788

789

790

791

792

793

794

795

796

797

Table and Figure Legends

Table 1. List and coordinates of sampling stations. Subtidal stations (23-27) are indicated by a circle.

\begin{tabular}{|c|c|c|}
\hline $\begin{array}{l}\text { Station } \\
\text { ID }\end{array}$ & $\begin{array}{l}\text { Station } \\
\text { locality }\end{array}$ & Coordinates (N/W) \\
\hline 1 & Polder & $48^{\circ} 23^{\prime} 3^{\prime \prime} / 4^{\circ} 26^{\prime} 6^{\prime \prime}$ \\
\hline 2 & Moulin Blanc & $48^{\circ} 23^{\prime} 44^{\prime \prime} / 4^{\circ} 25^{\prime} 55^{\prime \prime}$ \\
\hline 3 & Le passage & $48^{\circ} 23^{\prime} 25^{\prime \prime} / 4^{\circ} 23^{\prime} 03^{\prime \prime}$ \\
\hline 4 & Kéraliou & $48^{\circ} 22^{\prime} 35^{\prime \prime} / 4^{\circ} 24^{\prime} 41^{\prime \prime}$ \\
\hline 5 & Caro & $48^{\circ} 20^{\prime} 28^{\prime \prime} / 4^{\circ} 26^{\prime} 26^{\prime \prime}$ \\
\hline 6 & Tinduff & $48^{\circ} 20^{\prime} 2^{\prime \prime} / 4^{\circ} 22^{\prime} 03^{\prime \prime}$ \\
\hline 7 & Moulin Neuf & $48^{\circ} 21^{\prime} 5^{\prime \prime} / 4^{\circ} 21^{\prime} 04^{\prime \prime}$ \\
\hline 8 & Penfoul & $48^{\circ} 21^{\prime} 25^{\prime \prime} / 4^{\circ} 19^{\prime} 28^{\prime \prime}$ \\
\hline 9 & Kersanton & $48^{\circ} 20^{\prime} 45^{\prime \prime} / 4^{\circ} 18^{\prime} 2^{\prime \prime}$ \\
\hline 10 & Lanveur & $48^{\circ} 21^{\prime} 19^{\prime \prime} / 4^{\circ} 17^{\prime} 51^{\prime \prime}$ \\
\hline 11 & Rivière de Daoulas & $48^{\circ} 21^{\prime} 21^{\prime \prime} / 4^{\circ} 16^{\prime} 2^{\prime \prime}$ \\
\hline 12 & Château & $48^{\circ} 20^{\prime} 11^{\prime \prime} / 4^{\circ} 18^{\prime} 46^{\prime \prime}$ \\
\hline 13 & Moulin Mer & $48^{\circ} 18^{\prime} 56^{\prime \prime} / 4^{\circ} 17^{\prime} 11^{\prime \prime}$ \\
\hline 14 & Hôpital Camfrout & $48^{\circ} 19^{\prime} 37^{\prime \prime} / 4^{\circ} 14^{\prime} 53^{\prime \prime}$ \\
\hline 15 & Tibidy & $48^{\circ} 18^{\prime} 25^{\prime \prime} / 4^{\circ} 14^{\prime} 40^{\prime \prime}$ \\
\hline 16 & Lanvoy & $48^{\circ} 17^{\prime} 47^{\prime \prime} / 4^{\circ} 13^{\prime} 29^{\prime \prime}$ \\
\hline 17 & Térénez & $48^{\circ} 16^{\prime} 43^{\prime \prime} / 4^{\circ} 16^{\prime} 49^{\prime \prime}$ \\
\hline 18 & Landévennec & $48^{\circ} 17^{\prime} 34^{\prime \prime} / 4^{\circ} 15^{\prime} 29^{\prime \prime}$ \\
\hline 19 & Sillondes Anglais & $48^{\circ} 17^{\prime} 52^{\prime \prime} / 4^{\circ} 17^{\prime} 22^{\prime \prime}$ \\
\hline 20 & Fret & $48^{\circ} 16^{\prime} 54^{\prime \prime} / 4^{\circ} 30^{\prime} 13^{\prime \prime}$ \\
\hline 21 & Rostellec & $48^{\circ} 17^{\prime} 27^{\prime \prime} / 4^{\circ} 31^{\prime} 30^{\prime \prime}$ \\
\hline 22 & Persuel & $48^{\circ} 18^{\prime} 1^{\prime \prime} / 4^{\circ} 33^{\prime} 17^{\prime \prime}$ \\
\hline 230 & Port de Commerce & $48^{\circ} 22^{\prime} 7^{\prime \prime} / 4^{\circ} 29^{\prime} 18^{\prime \prime}$ \\
\hline $24 \circ$ & Le Passage & $48^{\circ} 23^{\prime} 39^{\prime \prime} / 4^{\circ} 22^{\prime} 54^{\prime \prime}$ \\
\hline $25 \circ$ & Auberlac'h & $48^{\circ} 19^{\prime} 9^{\prime \prime} / 4^{\circ} 25^{\prime} 53^{\prime \prime}$ \\
\hline 260 & EstTinduff & $48^{\circ} 19^{\prime} 7^{\prime \prime} / 4^{\circ} 20^{\prime} 7^{\prime \prime}$ \\
\hline $27 \circ$ & Lanveoc-Tinduff & $48^{\circ} 18^{\prime} 2^{\prime \prime} / 4^{\circ} 23^{\prime} 31^{\prime \prime}$ \\
\hline 280 & Quillien & $48^{\circ} 17^{\prime} 36^{\prime \prime} / 4^{\circ} 20^{\prime} 6^{\prime \prime}$ \\
\hline 290 & Ecole Navale & $48^{\circ} 17^{\prime} 37^{\prime \prime} / 4^{\circ} 24^{\prime} 6^{\prime \prime}$ \\
\hline 30 & Sainte Anne & $48^{\circ} 21^{\prime} 41^{\prime \prime} / 2^{\circ} 33^{\prime} 13^{\prime \prime}$ \\
\hline
\end{tabular}


Table 2. Summary of simulated particle trajectories initiating from four different areas in the Bay of

800 Brest: $F$ stands for the percentage of particles flushed out of the Bay of Brest at the end of the

801 simulation, $\mathrm{D}$ is the mean cumulative distance covered by particles until the end of the simulation

802 and A represents the percentage of particles still located in the estuary of release at the end of the

803 simulation (auto-connectivity). The two numbers stand for years 2014 and 2015, respectively.

804

805

806

807

\begin{tabular}{lcccc}
\hline $\begin{array}{l}\text { Release } \\
\text { station }\end{array}$ & 3 & 9 & 13 & 16 \\
\hline$F(\%)$ & $43.6-37.7$ & $9-18.7$ & $29.1-30.8$ & $23.5-24.2$ \\
$D(\mathrm{~km})$ & $129.5-127.9$ & $114.0-114.3$ & $151.1-149.7$ & $152.9-153.4$ \\
$A(\%)$ & $9.4-8.3$ & $26.5-26.2$ & $0-0$ & $12.8-10.4$ \\
\hline
\end{tabular}

808

809

810

811

812

813

814

815

816

817

818

819

820

821

822 
824

825

826

827

828

829

830

831

832

833

834

835

836

837

838

839

840

841

842

843

844

845

846

847

848

849

Table 3. Connectivity table between releasing stations $(3,9,13$ and 16$)$ and receiving areas (Elorn, Daoulas, Camfrout and Aulne estuaries). Percentage (\%) of particles reaching the considered area at least once in 10 days for 2014 and 2015, respectively.

7

8

\begin{tabular}{lcccc} 
& \multicolumn{4}{c}{ Releasing stations } \\
\hline & St. 3 & St. 9 & St. 13 & St. 16 \\
\hline Elorn estuary area & - & $0.3-0.2$ & $1.6-2.0$ & $2.0-0$ \\
Daoulas estuary area & $1.4-1.2$ & - & $29.7-28.4$ & $30.7-28.0$ \\
Camfrout estuary area & $0-0$ & $0.4-0$ & - & $6.6-6.0$ \\
Aulne estuary area & $1.3-1.5$ & $7.8-8.5$ & $58.7-57.4$ & - \\
\hline
\end{tabular}

(1) 


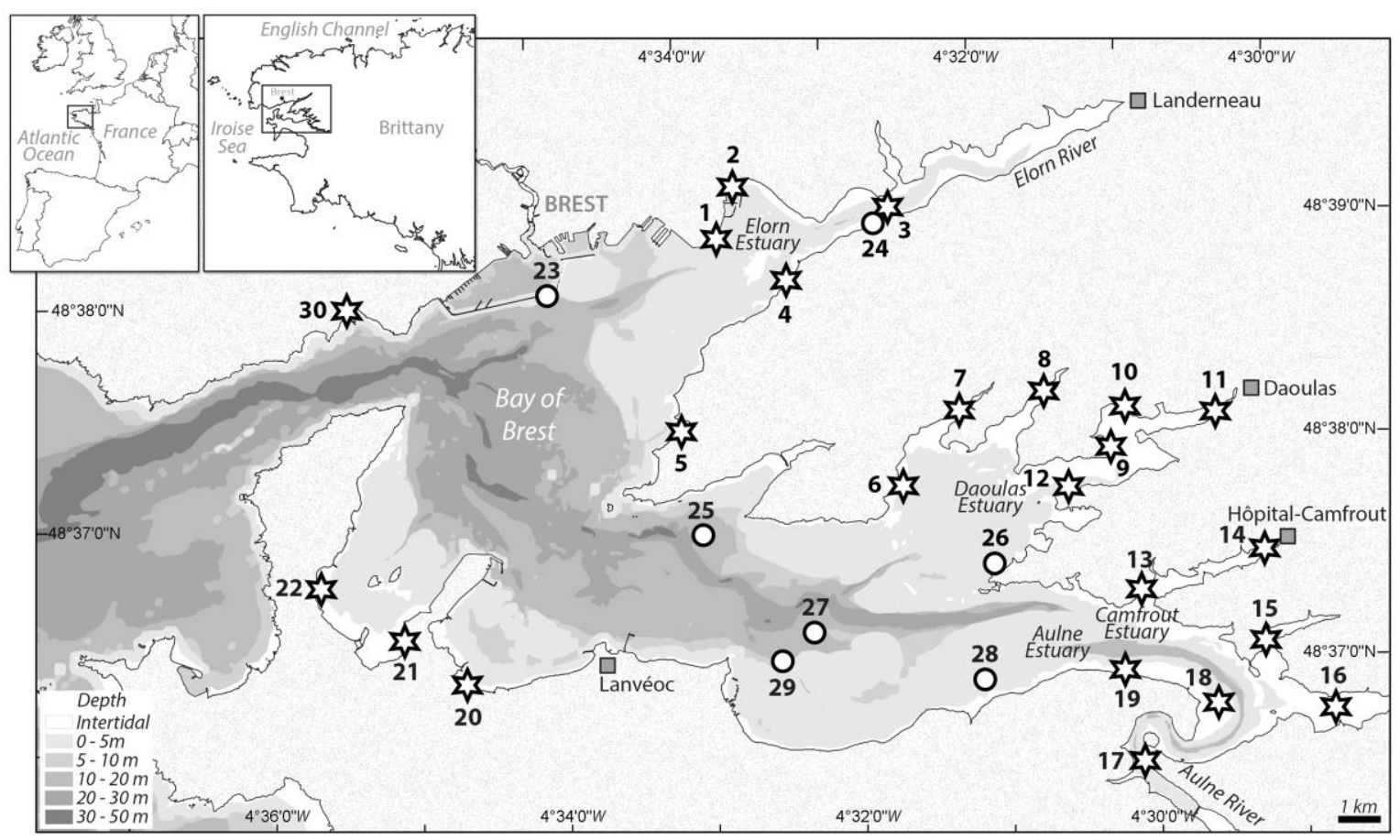


Figure 2: $\log 10(x+1)$ transformed real-time PCR data of Alexandrium minutum copy number $\mathrm{g}^{-1}$ of

868

869

870

871

872

873

874

875

876
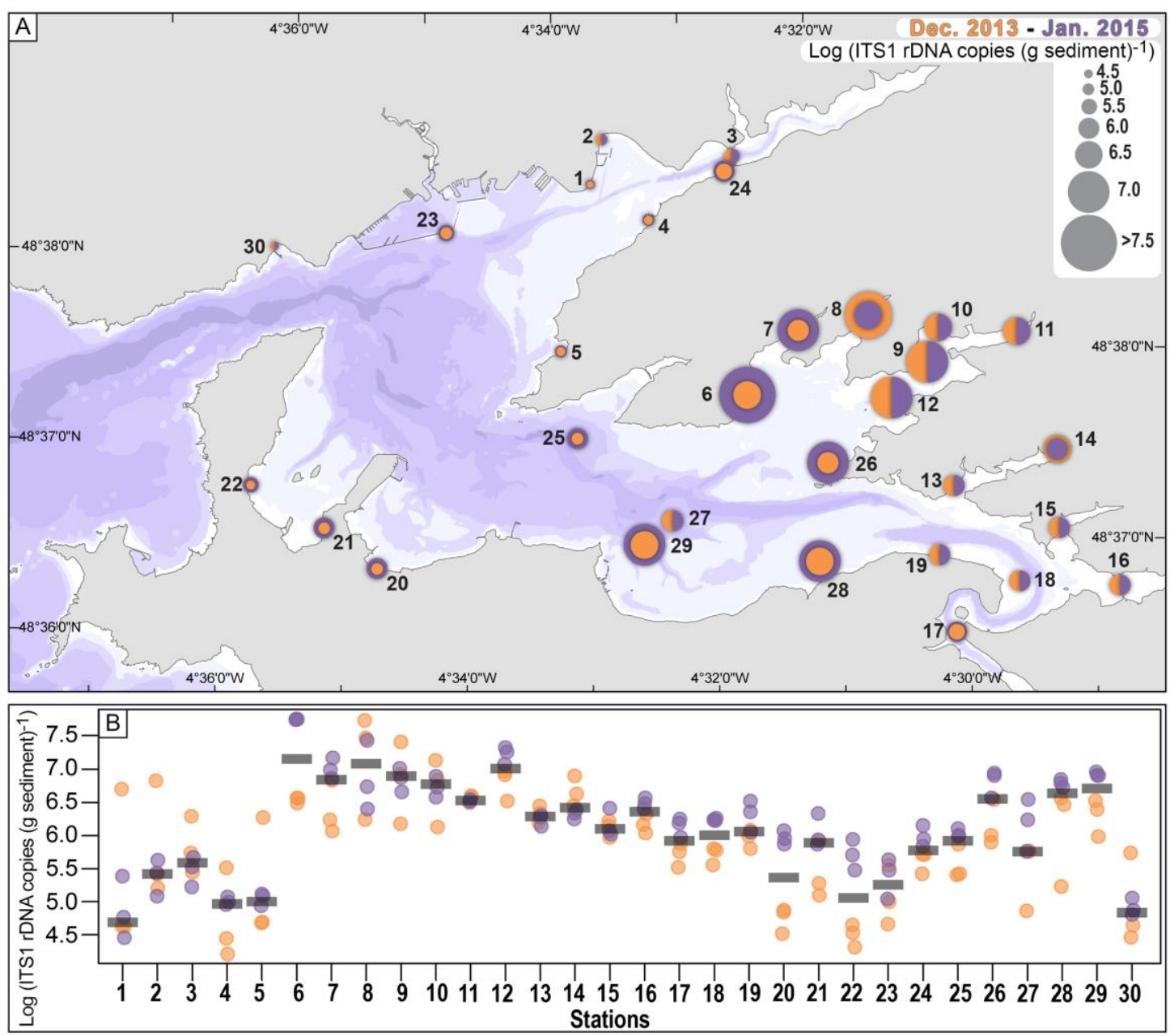
Figure 3. Relationship between environmental parameters (chlorophyll $a$ : $\mathrm{CHL} a$; organic carbon: OC,

881 sediment size class: 0-63, 63-125, 125-500 and 500-200 $\mu \mathrm{m}$ ), ITS1rDNA copy number concentration g $882{ }^{1}$ of sediment of Alexandrium minutum (A. minutum DNA) and total DNA concentration ( $\mathrm{ng} / \mathrm{\mu l}$ )

883

884

885

886

887

888

889

890

891

892
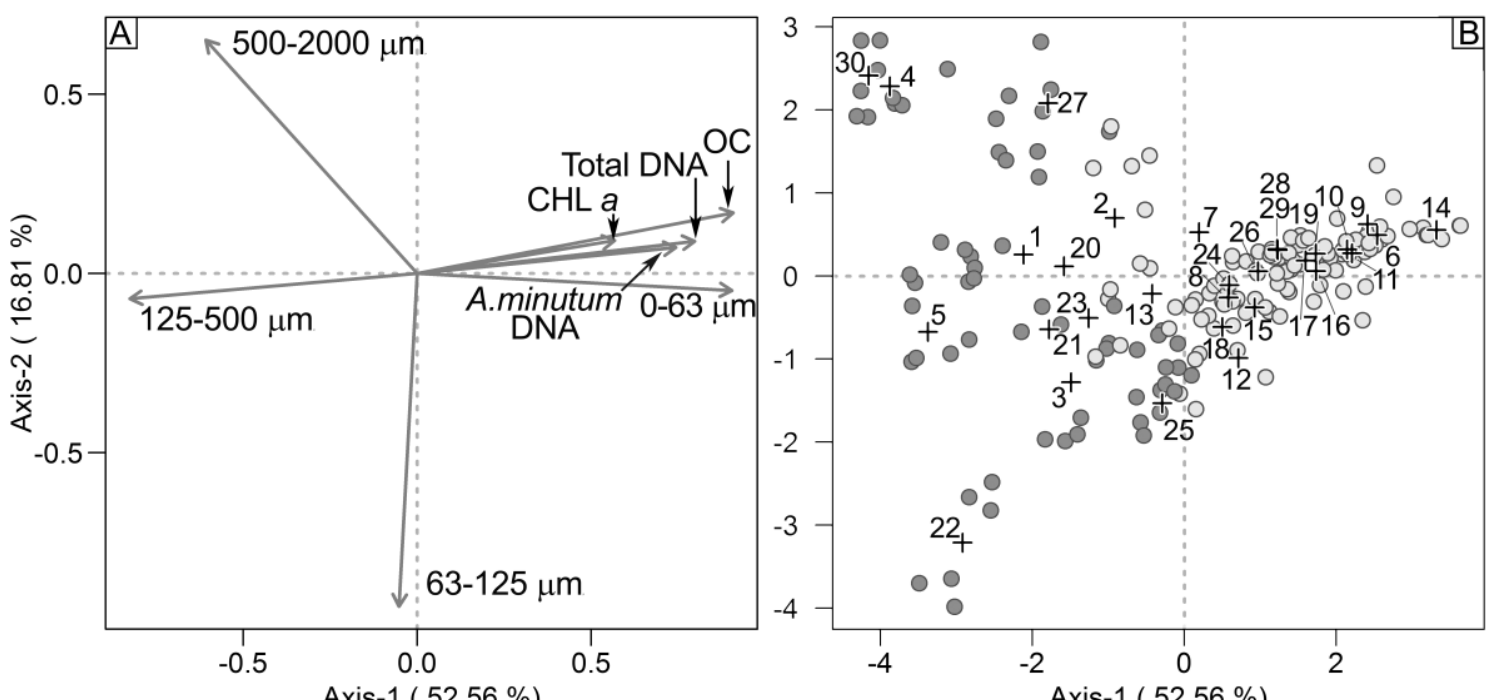

\begin{tabular}{|c|c|c|c|c|c|c|c|}
\hline \multicolumn{4}{|c|}{ Axis-1 ( $52.56 \%)$} & \multicolumn{4}{|c|}{ Axis-1 ( $52.56 \%$ ) } \\
\hline C] & $O C$ & Chla A. & . minutum DNA & total DNA & $0-63 \mu \mathrm{m}$ & $63-125 \mu \mathrm{m}$ & $125-500 \mu \mathrm{m}$ \\
\hline Chla & $\uparrow 0.47$ & & & & & & \\
\hline A. minutum DNA & 0.60 & 0.38 & & & & & \\
\hline total DNA & 0.69 & 0.70 & 0.67 & & & & \\
\hline $0-63 \mu \mathrm{m}$ & 0.83 & 0.28 & 0.54 & 0.58 & & & \\
\hline 63-125 $\mu \mathrm{m}$ & -0.17 & 0.13 & -0.06 & 0.06 & -0.15 & & \\
\hline $125-500 \mu \mathrm{m}$ & -0.77 & -0.21 & -0.49 & -0.53 & -0.90 & 0.22 & \\
\hline $500-2000 \mu \mathrm{m}$ & -0.57 & -0.13 & -0.32 & 0.32 & -0.72 & $\mid-0.05$ & 0.75 \\
\hline
\end{tabular}


Figure 4: Simulated trajectories of 1000 passive particles coming from 4 releasing estuarine stations and reaching delimited estuarine areas: A) station 3 (Elorn estuary); B) station 9 (Daoulas estuary); C) station 13 (Camfrout estuary); D) station 16 (Aulne estuary). Simulation duration is 10 days and final particle positions are given as black dots.

899
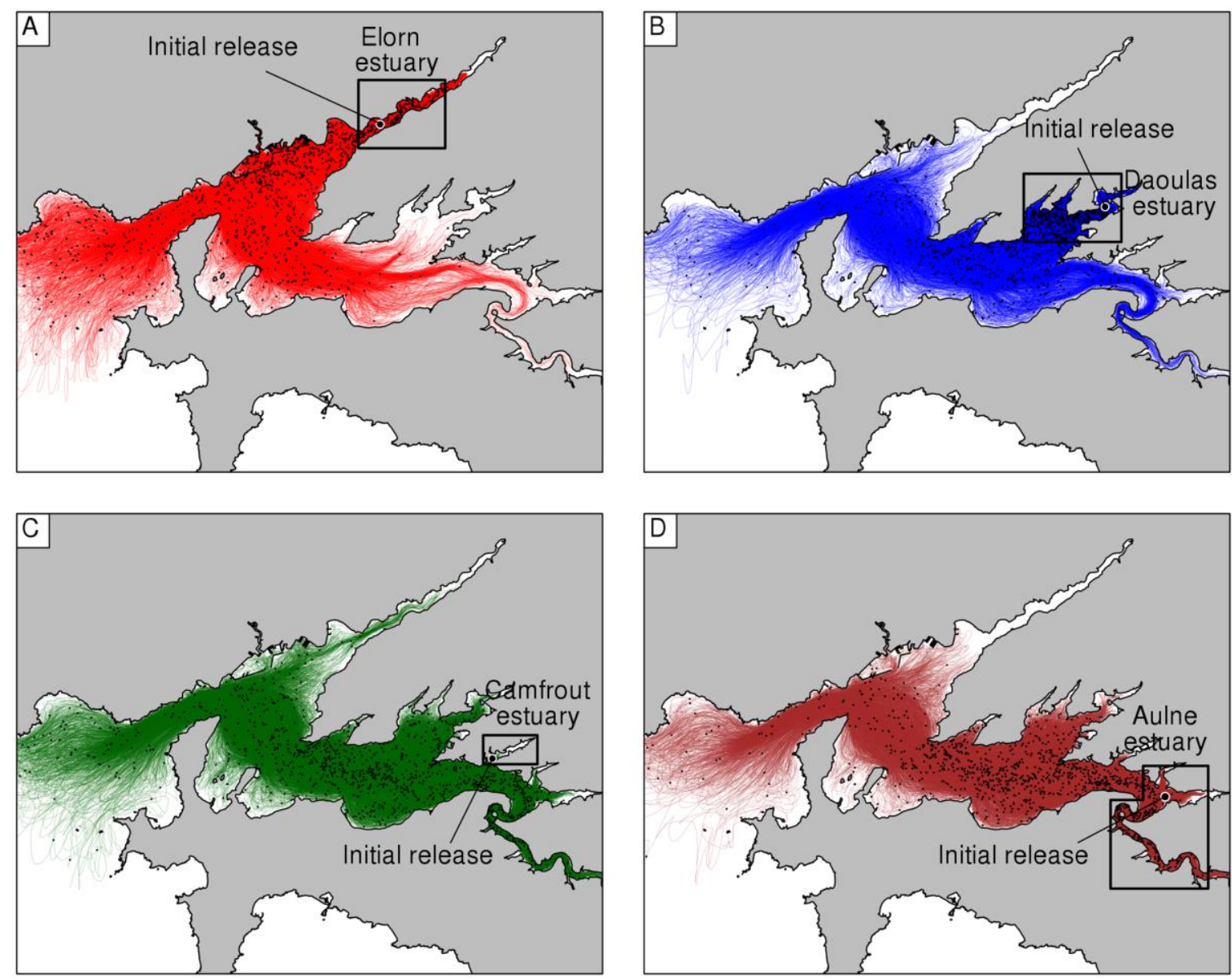

900

901

902

903

904

905

906 
908 Supp. Table 1. Classification of sampling stations based on four sediment size classes $(\mu \mathrm{m})$ following

909 Larsonneur (1977) for the two sampling surveys (January 2013 and December 2015).

910

$\begin{array}{lllll}\text { Id } & 0-63 & 63-125 & \mathbf{5 0 0 - 2 0 0 0} & \text { Classification } \\ \text { St. } & \mathbf{6} & \end{array}$

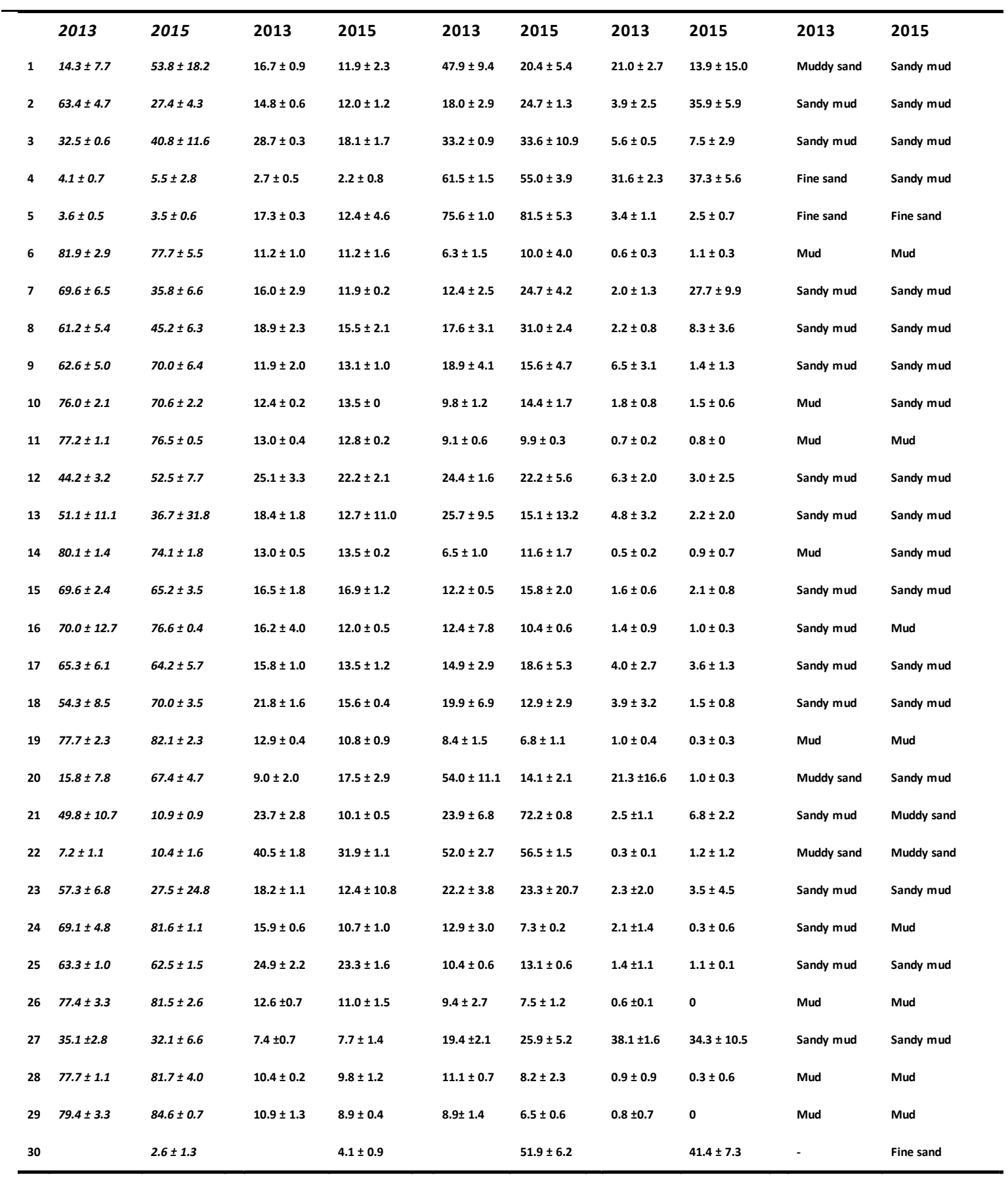

